\title{
Empirical Research on Professional Moral Cultivation of P.E. Teachers in Universities
}

\author{
Jiang Bo ${ }^{1}$, Chang Jindong ${ }^{1}$, Sun Yiwen ${ }^{2}$ \\ ${ }^{1}$ College of Physical Education, Southwest University, Chongqing, China \\ ${ }^{2}$ Faculty of Education, Southwest University, Chongqing, China \\ Email: jbo@swu.edu.cn
}

Received April 16 $6^{\text {th }}$, 2013; revised June $26^{\text {th }}$, 2013; accepted July $16^{\text {th }}, 2013$

\begin{abstract}
Copyright (C) 2013 Jiang Bo et al. This is an open access article distributed under the Creative Commons Attribution License, which permits unrestricted use, distribution, and reproduction in any medium, provided the original work is properly cited.
\end{abstract}

\begin{abstract}
Universities/college P.E. teachers play an important part in universities/colleges' development. Professional moral cultivation which acts as the professional attitude and professional standard is the basic ethics standard for college P.E. teachers. Through the investigation about eight universities P.E. teachers' current professional moral cultivation in Chongqing, this paper finds the de-criterion phenomenon in teachers' professional moral cultivation, then analyzes the influence factors, and puts forward some improving methods finally to provide theory basis for strengthening teacher's professional moral cultivation construction and enhance P.E. teacher's scientific research level in Chongqing.
\end{abstract}

Keywords: Universities/Colleges in Chongqing; P.E. Teacher; Professional Moral Cultivation; Current Situation

\section{Introduction}

"Moral cultivation" is a broad meaning concept; it means a person through long-term consciously learning, exercising and cultivating in ideological political, moral character and knowledge skill, and through efforts achieving some levels. Teacher's professional moral cultivation refers to when teachers engaged in education work, forming a stable career idea, behavior criterion and moral quality. It's the behavior standards to adjust teachers with others, group and social relationship. In the era with rapid high-tech development, university teachers carry the important task of educating and training the modern talents with high quality, strong ability and overall development. Universities PE teachers are not only the education workers, but also the sports workers, and they have deep influence on cultivating the successors with overall development (Pan Yongzhi, Zhang Chaojun, \& Zhang Kai, 2006). In order to find out the existing problems and deficiencies, this study investigates the PE Teachers' professional moral cultivation of 8 universities in Chongqing. Through discussing the structures and contents, taking the research experience from domestic and overseas, this study formulates feasible and operable suggestions for Chongqing col- lege PE teacher's professional moral cultivation to enhance teachers' comprehensive quality and professional level.

\section{Research Objects and Methods}

\section{Research Objects}

This study selected Chongqing University, Chongqing Normal University, Chongqing There Gorges University, Chongqing Technology and Business University, Chongqing Education College, Chongqing University of Posts and Telecommunications, Yangtze Normal University and Chongqing University of Arts and Science as the research objects, including 228 college PE teachers (Table 1) and 316 college students.

\section{Research Methods}

\section{Literature}

Consulting our country's related data about universities PE teachers' professional moral cultivation, meanwhile, studying some experts and scholars' research achievements about professional standards and professional cultivation.

Table 1.

Table of universities PE teachers' situation in Chongqing.

\begin{tabular}{|c|c|c|c|c|c|c|c|}
\hline \multirow{3}{*}{ Sex } & \multicolumn{6}{|c|}{ Professional title } & \multirow{3}{*}{$\mathrm{N}$} \\
\hline & \multicolumn{2}{|c|}{ Associate professor and above } & \multicolumn{2}{|c|}{ Instructor } & \multicolumn{2}{|c|}{ Teaching assistant } & \\
\hline & $\mathrm{n}$ & $\%$ & $\mathrm{~N}$ & $\%$ & $\mathrm{n}$ & $\%$ & \\
\hline male & 40 & 17.6 & 68 & 29.8 & 54 & 23.7 & 228 \\
\hline female & 23 & 10.1 & 28 & 12.2 & 15 & 6.6 & \\
\hline
\end{tabular}

Note: Teachers' object mainly refers to preparing teachers, except administrative personnel and logistics person. 


\section{Interview}

In March 2012, we interviewed eight universities' main leadership, administrative and management department's leadership and some of universities/college's PE teachers coming to southwest university for 2012 annual examination of professional sports of Chongqing.

\section{Questionnaire}

This study divided teacher's professional moral cultivation into six dimensions: loving job, caring for students, proficiency in business, exemplary virtue, obeying discipline and law, solidarity and cooperation. With the six dimensions, we formulate the questionnaires and send 245 questionnaires to 8 universities/colleges PE teachers, of which we recycle valid questionnaires 228 copies with effective recovery up to $93.1 \%$. At the same time, we also send 245 questionnaires to 8 universities/ colleges undergraduates (including professional sports, mainly aimed at loving students, proficient in business, exemplary virtue) and recycle valid questionnaires 316 poise with effective recovery up to $92.2 \%$.

\section{Research Results and Analysis}

\section{Analysis on the Dimension of Loving Job}

Loving job is the foundation of universities/college's PE teacher's professional moral cultivation, and it is also the basic morality of universities/college's PE teachers which plays a decisive role in the development of college P.E. teacher's professional moral cultivation. From Table 2, we can see universities/college's P.E. teachers are doing quite well in this respect. The lowest is over $80 \%$, especially the percentage of associate professors and above is over $85 \%$. Only a few instructors and teaching assistants can't do this very good.

\section{Analysis on the Dimension of Caring for Students}

Caring for students refers to the student-centered classroom, in which teachers respect each student, give judicious guidance according to the circumstance, teach students according to their aptitude, and mobilize students' enthusiasm and initiative fully. From Table 3 (for students' survey), we could know teachers do very well in the first four aspects with the lowest percentage is $81.3 \%$, however, for the last one, only associate professors and above can do this well with the percentage up to $84.3 \%$ and instructors and teaching assistants are only about $70 \%$. This shows that some young teachers do not emphasize students' growth enough, focusing on teach students knowledge but not educating their thoughts.

\section{Analysis on the Dimension of Proficiency in Business}

Teachers' professional quality mainly displays in three aspects with teaching, research and training, its height plays a direct impact on universities/college sports teaching. From Table 4, we can see teachers have done well in the first three aspects, but not very good in the last two. As a universities/college P.E.

Table 2.

The situation about teachers' loving their jobs.

\begin{tabular}{clcccc}
\hline \multirow{2}{*}{ Order } & \multicolumn{2}{c}{ The content of teachers' loving their jobs } & \multicolumn{3}{c}{ Teachers' completion situation (percentage: \%) } \\
\cline { 3 - 6 } & & Associate professors and above & Instructors & Teaching assistants & Average \\
\hline 1 & Loyalty to education career and dedication & 93 & 88.5 & 83 & 88.2 \\
2 & Loving school and maintaining school's honor & 89 & 82 & 81 & 84 \\
\multirow{2}{*}{3} & $\begin{array}{l}\text { Doing academic rigorously, with stable entrepreneur spirit, } \\
\text { handling the part-time job and the regular job correctly. }\end{array}$ & 85.3 & 76 & 79.4 & 80.2 \\
\hline
\end{tabular}

Table 3.

The situation about teachers caring for students.

\begin{tabular}{rlcccc}
\hline \multirow{2}{*}{ Order } & \multicolumn{2}{c}{ The content about caring for students } & \multicolumn{3}{c}{ Teachers' completion situation/\% } \\
\cline { 3 - 6 } & & Associate professors and above & Instructors & Teaching assistants & Average \\
\hline 1 & Treating students kindly and no punishment to students & 90.8 & 87.6 & 86 & 88.1 \\
2 & Respecting students on words and deeds & 87 & 85 & 85 & 85.7 \\
3 & Evaluating students' grades objectively & 85.5 & 81 & 80 & 82.2 \\
4 & Not damaging student's reputation in public or in private & 85 & 80.5 & 78.5 & 81.3 \\
& Treating each student equally, both teaching & 84.3 & 71.4 & 70.7 & 75.5 \\
\hline
\end{tabular}

Table 4.

The situation about proficiency in business.

\begin{tabular}{|c|c|c|c|c|c|}
\hline \multirow{2}{*}{ Order } & \multirow{2}{*}{ The content about proficiency in business } & \multicolumn{4}{|c|}{ Teachers’ completion situation/\% } \\
\hline & & Associate professors and above & Instructors & Teaching assistants & Average \\
\hline 1 & $\begin{array}{l}\text { Preparation lessons carefully and finishing } \\
\text { the teaching task effectively }\end{array}$ & 91.3 & 85.3 & 82.3 & 86.3 \\
\hline 2 & $\begin{array}{l}\text { Choosing advanced teaching methods and means, } \\
\text { fully mobilizing students' enthusiasm }\end{array}$ & 87.5 & 82.3 & 78 & 82.6 \\
\hline 3 & $\begin{array}{l}\text { Training conscientious, gaining excellent position } \\
\text { through hard work in competition }\end{array}$ & 85 & 81 & I & 83 \\
\hline 4 & Doing correct movement and technical movement in teaching & 70 & 73.6 & 76 & 73.2 \\
\hline 5 & $\begin{array}{l}\text { Doing scientific research consciously, } \\
\text { and publishing articles in major publications regularly }\end{array}$ & 43.1 & 31.7 & 15.7 & 30.2 \\
\hline
\end{tabular}


teacher, it's very important for teachers to let students accept teaching information vividly. But 26.8\% teachers (average) don't finish the task very well on the whole. It is understandable that some associate professors have certain pressure when they did the difficult movement (because of old age); but the young teachers don't exist age problem, they should consult to experienced teachers, strengthen practice skill, and try to do the correct demonstrations and norms movement.

Research is the universities' core competitiveness, but scientific research is the worst among the five aspects. Only $30.2 \%$ can do scientific research consciously and obtain some achievements. From teacher structure, we can see that associate professors and above have the highest percentage, second comes the instructors, and the last is the teaching assistants. This proportion forms a "pour pyramid" type and inevitably has extreme disadvantage to young teachers' growth and development. For teachers individually, scientific research is an important standard to promote, so young teachers should read more books, learn more knowledge, strengthen the theory knowledge, and improve the academic accomplishment.

\section{Analysis on the Dimension of Exemplary Virtue}

Exemplary virtue means that teachers must set a good example through their own behavior for students, and this is also the remarkable characteristic of teachers' career system. From Table 5, we can see teachers did very well in words and deeds. Associate professors and above, instructors and teaching assistant's average of the four major aspects are $90 \%, 83 \%$ and
$81.2 \%$ espectively. But each single indicator is not very ideal, only associate professors and above have high percentage and do well. In the last aspect, $28 \%$ instructor and assistant have sold textbooks and sporting goods to students for benefit, students didn't satisfy with instructor and assistant's actions. In addition, for the third aspect, $22 \%$ assistants also haven't done well. They need further strengthen and improve their accomplishment.

\section{Analysis on the Dimension of Observing Discipline and Law}

As the saying goes: "Nothing can be accomplished without norms or standards", human beings have established corresponding "regulations" in various fields to safeguard the social life, which need people consciously to obey in daily life in turn. Universities/colleges teachers should also do like this. They should become the exemplar of observing social ethics. From Table 6, we can see that teachers can set a strict demand on themselves to observe social ethics, administer education according to laws, comply with universities/colleges career system, and not violating the laws and competition rules. Compared with the above aspects, teachers do the best in the professional compliance.

\section{Analysis on the Dimension of Solidarity and Cooperation}

Solidarity and cooperation refer to teachers unite together for concentrating strength on achieving common ideal or task, they support mutually and cooperate closely. It's the behavior standard of teacher's interpersonal relationship. From Table 7's data, we can see teachers' team consciousness and cooperative

Table 5.

The situation about exemplary virtue.

\begin{tabular}{cllccc}
\hline \multirow{2}{*}{ Order } & \multirow{2}{*}{ The content about observing discipline and law } & \multicolumn{3}{c}{ Teachers' completion situation/\% } \\
\cline { 3 - 6 } & \multicolumn{1}{c}{ Not violating laws } & Associate professors and above & Instructors & Teaching assistants & Average \\
\hline 1 & & 100 & 100 & 100 & 100 \\
2 & Abiding social public morals consciously and leading example & 97 & 93 & 94 & 94.7 \\
3 & $\begin{array}{l}\text { Abiding the professional system and no late, } \\
\text { leaving early, truancy phenomenon }\end{array}$ & 94 & 90 & 92 & 92 \\
4 & $\begin{array}{l}\text { Not violating the competitions rules } \\
\text { (Including leading and personal game) }\end{array}$ & 93 & 87 & 85 \\
\hline
\end{tabular}

Table 6.

The situation about observing discipline and law.

\begin{tabular}{rlrccc}
\hline \multirow{2}{*}{ Order } & \multicolumn{2}{c}{ The content about observing discipline and law } & \multicolumn{3}{c}{ Teachers' completion situation/\% } \\
\cline { 2 - 6 } & \multicolumn{1}{c}{ Associate professors and above } & Instructors & Teaching assistants & Average \\
\hline 1 & Not violating laws & 100 & 100 & 100 & 100 \\
2 & Abiding social public morals consciously and leading example & 97 & 93 & 94 & 94.7 \\
3 & $\begin{array}{l}\text { Abiding the professional system and no late, } \\
\text { leaving early, truancy phenomenon }\end{array}$ & 94 & 90 & 92 & 92 \\
\multirow{2}{*}{4} & $\begin{array}{l}\text { Not violating the competitions rules } \\
\text { (Including leading and personal game) }\end{array}$ & 93 & 87 & 85 & 88.3 \\
\hline
\end{tabular}

Table 7.

The situation about solidarity and cooperation.

\begin{tabular}{rlccc}
\hline \multirow{2}{*}{ Order } & \multicolumn{2}{c}{ The content about solidarity and cooperation } & \multicolumn{2}{c}{ Teachers' completion situation/\% } \\
\cline { 2 - 5 } & \multicolumn{1}{c}{ Associate professor and above } & Instructor & Assistant & Average \\
\hline 1 & Attending college, teaching-research section and party organization's affair actively & 88.5 & 90.2 & 92.3 \\
2 & Not bringing personal emotions into teachers group & 88 & 90.3 \\
& $\begin{array}{l}\text { Respecting colleagues' work achievement, } \\
\text { not envying others' ability, and not attacking others }\end{array}$ & 86.5 & 89.5 & 88.8 \\
& $\begin{array}{l}\text { Assisting colleagues, developing team spirit to } \\
4\end{array}$ & 83 & 88.6 & 87 \\
\hline
\end{tabular}


spirit is very well, the four contents' averages is $87.05 \%$; assistants behave more active in this aspect, the four contents' averages is $88.2 \%$. High degree of cooperation could help give full play to the advantage of every PE teacher, promote college PE teachers' teaching, training and academic research in Chong Qing.

\section{Conclusion and Analysis the Reasons}

\section{The Phenomenon Out-of-Standard of College P.E. Teachers' Professional Moral Cultivation}

1) There are some teachers existing the idea that only teach but not educate, the consciousness of education is desalt, and they neglect students' moral education. At the same time, some students think they are lack of communicating with teachers; teachers are only teach, but they cannot understand what's students thinking, so they can't targeted educate students.

2) Teachers' professional skill is not solid, classroom teaching demonstration is not accurate enough, and action is not standard. Meanwhile, there are some teachers' initiation insufficient when they learn new knowledge, they can't choose advanced teaching methods and means, and can't mobilize students' enthusiasm fully. In addition, teachers' scientific research consciousness and ability should be enhanced urgently, some teachers are lack of the scientific attitude that steadfast-rigorous and striving for perfection, they are not like scientific research, exist the phenomenon of unsuspecting target and forgery.

3) Some teachers exist low moral cultivation, they can not lead by example and exemplary virtue, only rely on individual rights selling materials and sporting goods to students for benefit.

\section{Analysis the Reason of College P.E. Teachers' Professional Moral Cultivation Out-of-Standard}

\section{The Tide of Market Economic Influence College P.E.} Teachers' Professional Quality

Along with our country's socialist market economy system gradually establishment, there are also more and more corresponding conditions which beneficial for the development of education and sports; however, there are also some certain negative effects on some fields development with the emergence of these conditions. College PE teachers can't separate themselves from the tide of market economic; some teachers are influence on the negative effects, having the thoughts that fraud and chase individual fame, and appeared the distortion of the personality (Chen Linong, 2003). Eventually teachers' enthusiasms are impaired, and professional quality is weakened.

\section{The Influence of University Teachers' Professional Ethics Education Restriction System Deficiency}

The deficiency of university teachers' professional ethics education restriction system means that universities take teaching management and scientific research improvement seriously, and neglect teachers' virtue and image shaping, don't have an important agenda about teachers' professional ethics education (Huang Rongsheng, 2000). The representations specific display in those aspects: no single teachers' professional ethics education plan; teachers' professional ethics education contents pertinence are not very well, lacking originality; monotonous form, lacking interest in learning. Now, education management departments and university don't have perfect rules to restrict PE teachers' professional ethics, these make teachers' professional ethics education obviously deficiencies.

\section{The Influence of Teachers' Themselves in the Professional Quality}

Teachers ideological quality and professional quality decreasing because of the above influence, even some teachers lack professional dedication and rigorous research attitude, they are satisfied with status quo and don't want to be better (Xia Duanyang, 2008). Meanwhile, traditional prejudice and old idea influence the PE teachers' enthusiasm; what's more, PE teacher's social position is not high. Although these problems don't represent the PE teachers' mainstream, but these still make teachers social prestige down in a length of period (Xie Xiangyang, Liu Jiangnan, \& Sun Hongtao, 2003).

\section{The Promotion Measures of College Teacher's Professional Moral Cultivation}

1) Beginning with the management system reform, establish that management system which adapt to teacher's professional moral cultivation construction, and let the rewards and punishments distinctly, use "ruthless" system implementing "affectionate” education; Implement two-way choice gradually, and form a dynamic management system that "position can promote and demote, treatment can high and low, staff can be in and out”.

2) Pay attention to the standardization of teacher's professional moral cultivation construction, and establish operable scientific evaluation system, in order to ensure teachers have rules to depend and follow when they form vocational moral habit and public evaluate their behavior.

3) Perfect the examination and incentive system, establish teacher's professional moral cultivation evaluation system that schools, teachers and students participate together, treat the evaluation results as the important basis of teachers hiring, assessment, promotion, rewards and punishments. We must commend and encourage outstanding teachers, and adopt few punishment measures to protect teachers' enthusiasm.

4) Strengthen scientific and theoretical study, innovate teaching methods and improve their professional qualities. In the 21st century, college teachers should pay more attention to professional levels, teacher must study for a real teacher, try to have solid foundation of basic skills and profound theories, broad their academic vision, pursue the spirit of excellence.

5) Renew the education idea and cultivate morality by virtue, create new teacher-student relationship, change the "pass-on type" education mode which form in the traditional relationship that "one day for teacher, whole life for father" between teachers and students, and form the science, democracy and equal "new friendship type" teacher-student relationship which establish in the process of imparting and inheriting about moral cultivationand knowledge skill.

\section{Acknowledgements}

This research was supported by "the Fundamental Research Funds for the Central Universities (Grant No. SWU1109072)" and "the Fundamental Research Funds for the Central Universities (Grant No. SWU1309232)”, the Humanities and Social Science Research Youth Foundation of the Ministry of Education in China (Grant No. 12YJC880005) and Chongqing Higher Education Reform Project (No. 120388). 


\section{REFERENCES}

Chen, L. N. (2003). Discuss the diathesis of sports teacher in the times of intellectual economy. Journal of Guangzhou Physical Education Institute, 23, 112.

Huang, R. S. (2000). Teachers’ professional morality (p. 260). Beijing: Higher Education Press.

Pan, Y. Z., Zhang, C. J., \& Zhang, K. (2006). Research on the status quo of teacher virtue of Beijing Sport University. Journal of Beijing
Sport University, 50, 1235-1237.

Xie, X. Y., Liu, J. N., \& Sun, H. T. (2003). The contribution of physical education of the colleges and universities on quality education and its reform. Journal of Physical Education, 17, 72-74.

Xia, D. Y. (2008) College P.E. teachers professional ethics anomie and its countermeasure in Hubei province. Journal of Wuhan Institute of Physical Education, 42, 86-89. 